Jahr, H. M. (1936). Thyroid 'poisoning' in children. Nebraska State Medical fournal, 21, 388.

Levy, R. P., and Gilger, W. G. (1957). Acute thyroid poisoning. New England fournal of Medicine, 256, 459.

Schottstaedt, E. S., and Smoller, M. (1966). 'Thyroid storm' produced by acute thyroid hormone poisoning، Annals of Internal Medicine, 64, 847.

Stanage, W. F., and Henske. J. A. (1955). Accidental ingestion of poisons. Fournal of Pediatrics, 47, 470.

P. Gerard, P. MalvauX, ${ }^{\star}$ and M. DE VISSCHER

Department of Pediatrics and Laboratoire de Pathologie Générale, University of Louvain, Belgium.

^Correspondence to Dr. P. Malvaux, Department of Pediatrics, Cliniques Universitaires St-Raphaël, 3000-Louvain, Belgium.

\title{
Raised Immunoglobulin Levels and Thrombocytosis in Infantile Cortical Hyperostosis
}

Infantile cortical hyperostosis is characterized by swelling of soft tissues and cortical thickening of underlying bone, usually within the first 3 months of life. The mandible is almost always involved (Caffey, 1961). Fever is a common finding and pseudoparalysis has been observed in many patients (Gwinn and Barnes, 1967). Constant laboratory findings include a raised erythrocyte sedimentation rate, a raised serum alkaline phosphatase, and anaemia. Complete recovery is usual, though occasionally recurrences or death have been reported.

\section{Case Report}

A male infant, aged 9 weeks, was admitted on 12 February 1970 with a 7-day history of not moving his right arm. He had been a normal delivery at term after an uneventful pregnancy. His birthweight was 4.09 kg. He had progressed satisfactorily up to the onset of the recent illness. He was the youngest of 5 children; the elder sibs and the parents were healthy and showed no abnormal features. He was pale and had an unusually broad face, particularly the lower jaw. There was no obvious lesion visible to account for the lack of movement in the right arm. His weight on admission was $5 \cdot 34 \mathrm{~kg}$.

$X$-rays confirmed the suspicion that the patient had infantile cortical hyperostosis (Fig). There was marked periosteal thickening of both mandibles, clavicles, scapulae, and of the anterior rib ends. Slight periosteal thickening along the shafts of both femora, tibiae, and humeri was also observed.

The following investigations were carried out: alkaline phosphatase $40 \mathrm{~K}-\mathrm{A}$ units $\%$; serum calcium $9 \cdot 1 \mathrm{mg} / 100 \mathrm{ml}$; serum phosphate $6.7 \mathrm{mg} / 100 \mathrm{ml}$; Wassermann reaction negative; uric acid $3.7 \mathrm{mg} / 100$ $\mathrm{ml}$; blood urea $16 \mathrm{mg} / 100 \mathrm{ml}$; serum iron $15 \mu \mathrm{g} / 100 \mathrm{ml}$; serum vitamin B12 $500 \mathrm{pg} / \mathrm{ml}$; serum folic acid $6 \cdot 1$ $\mathrm{ng} / \mathrm{ml}$; throat swab, no pathogenic growth; faeces, no

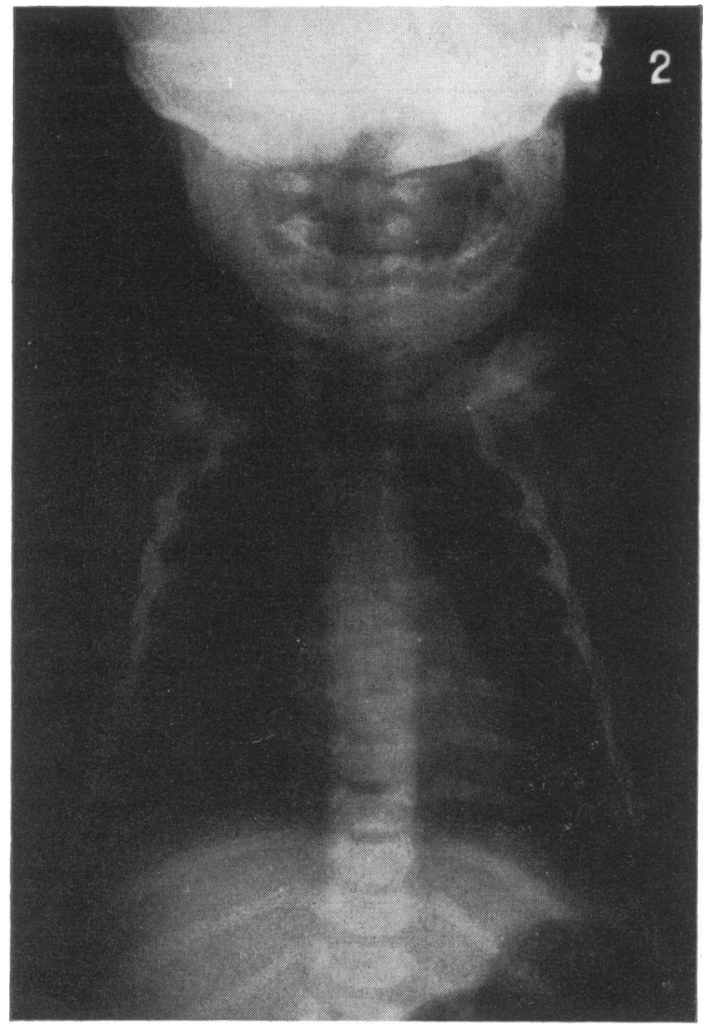

FlG.-Radiological evidence of infantile cortical hyperostosis.

pathogenic growth; urinalysis normal; osmotic fragility test, mean corpuscular fragility $0.44 \%$; Coombs test negative; R.A. Latex test weak positive; Rose Waaler positive to $1 / 48$; L.E. Latex serological test negative; antinuclear test negative; thyroid Latex tanned red cell agglutination test and complement-fixation tests for thyroid antibodies negative; parietal cell antibody test negative.

A summary of haematological investigations is shown in Table I. On admission the patient was anaemic and had an ESR of $44 \mathrm{~mm} / \mathrm{hr}$. The white cell count

TABLE I

Haematological Investigations

\begin{tabular}{l|c|c|c}
\hline \multicolumn{1}{c|}{ Date } & $\begin{array}{c}\mathrm{Hb} \\
(\mathrm{g} / 100 \mathrm{ml})\end{array}$ & WBC $/ \mathrm{mm}^{3}$ & Platelets $/ \mathrm{mm}^{3}$ \\
\hline 13 February 1970 & $7 \cdot 6$ & 8,800 & \\
25 February 1970 & $8 \cdot 7$ & 13,100 & $1,200,000$ \\
12 March 1970 & $7 \cdot 9$ & 20,100 & \\
28 April 1970 & $9 \cdot 9$ & 9,200 & 620,000 \\
4 September 1970 & $11 \cdot 4$ & 10,400 & 487,000 \\
& & & \\
\hline
\end{tabular}


rose from 8800 to $20,000 / \mathrm{mm}^{3}$ when the differential count was neutrophils $30 \%$, eosinophils $5 \%$, lymphocytes $55 \%$, monocytes $10 \%$. The leucocyte alkaline phosphatase score was 181 . Shortly after admission the platelet count was $1,200,000 / \mathrm{mm}^{3}$ gradually falling to $487,000 / \mathrm{mm}^{3}$ at 39 weeks. The bone marrow was hyperplastic, the myeloid erythroid ratio 1 to 1 , and megakaryocytes abundant.

The immunoglobulin levels were measured by the gel diffusion technique (Hyland Laboratories). Results were compared against normal values reported by Stiehm and Fudenberg (1966). The most obvious and consistent change was a rise in the $\operatorname{IgM}$ level (Table II). In the early phase there was also a rise

TABLE II

Immunoglobulin Levels

\begin{tabular}{l|c|c|c|c}
\hline \multicolumn{1}{c|}{ Date } & Age (wk) & IgG & IgA & IgM \\
\hline 19 February 1970 & 10 & 1,100 & 86 & 148 \\
10 March 1970 & 13 & 1,500 & 66 & 140 \\
28 April 1970 & 20 & 1,100 & 68 & 120 \\
4 September 1970 & 39 & 700 & 76 & 26 \\
\hline Normal range at & $4-12$ wk $^{\star}$ & $272-762$ & $6-56$ & $16-67$ \\
\hline
\end{tabular}

^Stiehm and Fudenberg, 1966.

in IgG and a less marked rise in IgA. Immunoelectrophoresis did not reveal abnormal bands.

Immunoglobulin assays, blood counts, platelet counts, serum calcium, and alkaline phosphatase estimations were carried out on the parents and sibs. All the results were within normal limits.

The pseudoparalysis cleared up without treatment and he made a complete recovery. The size of the clavicles gradually diminished noticeably within 2 months, and this was confirmed radiologically. The mandible took longer to return to normal. Immunoglobulin levels and haematological values were within normal limits 7 months after the onset of symptoms.

\section{Discussion}

The purpose of this communication is twofold: to stress the occurrence of thrombocytosis and to describe a possible new finding of raised immunoglobulin levels in infantile cortical hyperostosis. Pickering and Cuddigan (1969) could find only 6 reported cases of Caffey disease with a high platelet count, 2 of which had concomitant thrombosis of the external jugular veins. The patient described in the present communication recovered satisfactorily without evidence of thrombosis despite a platelet count of $1,200,000$ per $\mathrm{mm}^{3}$. The cause of thrombocytosis is unknown.

Rise of IgM immunoglobulin has been observed during the first 6 months of life, with a fall to normal levels at about 6 months in patients with intrauterine virus infections (Dudgeon, Marshall, and Soothill, 1969). A lesser rise in IgG and IgA levels during the first 6 months in rubella infants has also been noted (McCracken et al., 1969). This pattern is similar to that observed in the case described in this communication. It seems possible, therefore, that infantile cortical hyperostosis, a condition without known aetiology, may be due to a viral infection during intrauterine life or early in the neonatal period.

\section{Summary}

One case of infantile cortical hyperostosis is reported. Throughout the acute phase of the condition there was a rise of all immunoglobulins. The rise in IgM was particularly obvious. Similar rises have been observed in viral infections during intrauterine life and in infancy. Anaemia and a raised platelet and white cell count were also observed.

\section{REFERENCES}

Caffey, J. P. (1961). Pediatric X-ray Diagnosis, 4th ed., p. 1014 Year Book Medical Publishers, Chicago.

Dudgeon, J. A., Marshall, W. C., and Soothill, J. F. (1969). Immunological responses to early and late intrauterine virus infections. Fournal of Pediatrics, 75, 1149

Gwinn, J. L., and Barnes, G. R. (1967). Radiological case of the month. American fournal of Diseases of Children, 113, 471.

McCracken, G. H., Hardy, J. B., Chen, T. C., and Sever, J. L. (1969). Evaluation of a radial diffusion plate method for determining serum immunoglobulin levels in normal and congenitally infected infants. Fournal of Pediatrics, 75, 1204.

Pickering, D., and Cuddigan, B. (1969). Infantile cortical hyperostosis associated with thrombocythaemia. Lancet, $2,464$.

Stiehm, E. R., and Fudenberg, H. H. (1966). Serum levels of immune globulins in health and disease: a survey. Pediatrics, 37, 715 .

I. J. Temperley, ^ S. J. Douglas, and J. P. R. Rees The National Children's Hospital, and Department of Paediatrics, Trinity College, Dublin 2.

^Correspondence to Dr. I. J. Temperley, National Children's Hospital, Harcourt Street, Dublin 2, Eire. 